\title{
Favourableness and connectivity of a Western Iberian landscape for the reintroduction of the iconic Iberian ibex Capra pyrenaica
}

\author{
Rita T. Torres, João Carvalho, Emmanuel Serrano, Wouter Helmer \\ Pelayo ACEVEdo and Carlos Fonseca
}

\begin{abstract}
Traditional land use practices declined throughout many of Europe's rural landscapes during the 2oth century. Rewilding (i.e. restoring ecosystem functioning with minimal human intervention) is being pursued in many areas, and restocking or reintroduction of key species is often part of the rewilding strategy. Such programmes require ecological information about the target areas but this is not always available. Using the example of the Iberian ibex Capra pyrenaica within the Rewilding Europe framework we address the following questions: (1) Are there areas in Western Iberia that are environmentally favourable for reintroduction of the species? (2) If so, are these areas well connected with each other? (3) Which of these areas favour the establishment and expansion of a viable population of Iberian ibex in a reintroduction programme? We modelled environmental favourableness for the species in the Iberian Peninsula using a logistic regression with a forward-backward stepwise procedure, and assessed landscape connectivity using a graph analytical approach after downscaling the model to the Western Iberia region. Our results indicate that several habitat patches in the study area present favourable environmental conditions for reintroduction of the Iberian ibex. Overall, most of the habitat connectivity was concentrated in northern and central patches. We highlight the potential and practical application of the analytical protocol used, for successful integration of species distribution modelling and landscape connectivity in the design of broad-scale reintroduction and recovery programmes.
\end{abstract}

Rita T. TorRes $\dagger$ (Corresponding author), JoÃo Carvalho†, Emmanuel SerRano* and Carlos Fonseca Department of Biology \& Centro de Estudos do Ambiente e do Mar, University of Aveiro, 3810-193 Aveiro, Portugal

E-mail rita.torres@ua.pt

WOUter Helmer Rewilding Europe, Toernooiveld, Nijmegen, Netherlands

Pelayo Acevedo Instituto de Investigación en Recursos Cinegéticos, Consejo Superior de Investigaciones Científicas (CSIC), Universidad de Castilla-La Mancha (UCLM) and Junta de Comunidades de Castilla-La Mancha, Ciudad Real, Spain

*Also at: Servei d'Ecopatologia de Fauna Salvatge, Departamento de Medicina y Cirugia Animal, Universidad Autónoma de Barcelona, Bellaterra, Barcelona, Spain

$\dagger$ Both authors contributed equally.

Received 1 April 2016. Revision requested 16 May 2016.

Accepted 22 June 2016. First published online 5 October 2016.
Keywords Capra pyrenaica, environmental favourableness, graph theory, habitat connectivity, Iberian ibex, reintroduction, ungulate

\section{Introduction}

an has shaped landscapes for centuries (Vos \& 1 Meekes, 1999). In the last 4 decades socio-economic and lifestyle changes have driven a rural exodus and the abandonment of land throughout many of Europe's rural landscapes (MacDonald et al., 2000; Höchtl et al., 2005). In some cases sociocultural and economic problems have created new opportunities for conservation (Theil et al., 2005). Land abandonment and degradation, rural depopulation and the perception of the presence of small pockets of intact nature has increased the interest in wilderness throughout Europe, and rewilding has emerged as a novel concept within restoration and conservation management (for a review, see Jepson, 2015). Rewilding aims to restore ecosystem functioning with minimal human intervention (Sandom et al., 2012), which cannot be achieved without the reintroduction of species that have key roles in shaping the landscape (McKnight, 2014). In this context a fundamental part of the minimal human intervention is the reintroduction of keystone species (Schadt et al., 2002; Manning et al., 2009; Sandom et al., 2012; Cianfrani et al., 2013). Since 2011 the Rewilding Europe project has been active in turning land abandonment problems into opportunities (Helmer et al., 2015). One of its most emblematic projects aims to reintroduce viable and self-sustaining populations of the European bison Bison bonasus in connected areas across Europe (van de Vlasakker, 2014). In the Iberian Peninsula (Portugal and Spain) an important goal of Rewilding Europe is to develop natural grazing systems to facilitate the return of iconic and ecologically important species such as the Iberian ibex Capra pyrenaica, the wild rabbit Oryctolagus cuniculus and the Iberian lynx Lynx pardinus, which are considered to be key species in this region.

Modelling the environmental favourableness and landscape connectivity of a territory in the context of a reintroduction programme is particularly challenging because ecological data on the species to be reintroduced are usually not available for the target area. To date, little has been done on the application of species distribution models in 
planning the recovery of reintroduced species (Chauvenet et al., 2015) within the Rewilding Europe framework. However, the first step in any reintroduction programme is to identify favourable areas for a species and the connectivity between those areas. This is required to optimize the success of reintroduction and the establishment and dispersal of the introduced population (Armstrong \& Seddon, 2008).

The Iberian ibex is an emblematic species that was once widely distributed in the Iberian Peninsula and French Pyrenees (Pérez et al., 2002). In the 2oth century hunting pressure, habitat loss and outbreaks of sarcoptic mange led to a local reduction, and consequently fragmentation, of wild goat populations (Pérez et al., 2002). Of the four subspecies described by Cabrera (1911) only two are extant: $C$. pyrenaica hispanica and C. pyrenaica victoriae. Capra pyrenaica lusitanica inhabited the north-western corner of the Iberian Peninsula and went extinct in the last decades of the 19th century, and C. pyrenaica pyrenaica inhabited the Pyrenees and has been considered to be extinct since 2002. However, several translocations were carried out in the last decades of the 2oth century and $C$. pyrenaica currently has a wide distribution in Spain (Acevedo \& Cassinello, 2009). In 1997 individuals of the subspecies $C$. pyrenaica victoriae were reintroduced in north-west Spain, in Baixa Limia-Serra do Xurés National Park (a transboundary park with Portugal), from the Gredos mountains of central Spain (Moço et al., 2006). This subspecies is categorized as Critically Endangered in the Portuguese Red Data Book (Cabral et al., 2005), Near Threatened in the Spanish Red Data Book (Acevedo \& Cassinello, 2009) and Least Concern on the IUCN Red List (Herrero \& Pérez, 2008). The Iberian ibex is considered to be a mixed feeder (browser and grazer), dependent on plant availability (Moço et al., 2013; Perea et al., 2015). It is also an ecosystem engineer as it creates and modifies habitats, with significant effects on ecosystem functioning (Byers et al., 2006).

The Western Iberia region (a montado-sierra landscape in Portugal, bordering Spain) is one of five pilot areas selected for the Rewilding Europe project. This is a rural area in the interior of Portugal, where land abandonment and rural depopulation have resulted in the density of people and roads being generally low.

We applied a two-fold analytical framework to address the following questions related to planning the reintroduction of the Iberian ibex within the Rewilding Europe perspective: (1) Are there areas in central Western Iberia that are environmentally favourable for the Iberian ibex? (2) If so, are these areas well connected with each other? (3) Which of these areas favour the establishment and expansion of a viable population of Iberian ibex in a reintroduction programme? Firstly, we modelled the distribution of the Iberian ibex in the Iberian Peninsula using a UTM (Universal Transverse Mercator) grid of $10 \times 10 \mathrm{~km}$ cells. Secondly, we downscaled the model to central Western Iberia, our area of interest, using a UTM grid of $1 \times 1 \mathrm{~km}$ cells. Finally, we evaluated the connectivity between the favourable localities in Western Iberia. By quantifying the importance of each individual habitat area it is possible to focus conservation and management actions directly on those areas that have greater importance for overall connectivity.

\section{Study area}

The Iberian Peninsula is a heterogeneous territory. There are four main climatic types: Atlantic (mild year-round, with abundant rainfall spread throughout the year; typical of the north-west areas), Continental (wide annual temperature range among seasons), Mediterranean (warm and dry summers and mild winters), and Semi-arid (drought and hot summers). These characteristics play a key role in the distribution of biodiversity (Tenorio et al., 2005). The study was focused on the Western Iberia region, in an area of 1,064 $\mathrm{km}^{2}$ in the valley of the River Côa (Fig. 1). At a coarse scale the climate is predominantly dry and Mediterranean, with some Atlantic influence, mainly in the northern and western areas. The temperature is frequently $>40^{\circ} \mathrm{C}$ in late spring and summer, daily thermal amplitudes may reach $10-15^{\circ} \mathrm{C}$ and annual precipitation is often $<400 \mathrm{~mm}$. The vegetation is varied and characterized by Quercus suber, Quercus pyrenaica, Quercus rotundifolia and mixed patches interspersed with understorey species such as Erica australis, Pterospartum tridentatum, Halimium alyssoides and Cistus ladanifer. The area is crossed by a diversity of rivers and small streams. Scattered cultivated areas are mainly planted with vines and olive and almond trees. Sympatric ungulates include the semi-wild garrano Equus ferus caballus, the wild boar Sus scrofa and the roe deer Capreolus capreolus. The area has a low human population density and was one of the areas historically occupied by the Iberian ibex, probably $C$. pyrenaica lusitanica (Cabrera, 1911).

\section{Methods}

The variables used to model the distribution of the Iberian ibex were selected based on information about the species' ecology (Granados et al., 2001; Pérez et al., 2002; Acevedo et al., 2007a; Acevedo \& Real, 2012). These variables included gradients related to habitat structure and vegetation productivity, topographical features and human disturbance (Table 1). The habitat structure comprised three broad land use/land cover categories: forest stands, agricultural fields and scrubland. Forest stands are important as they provide cover for the species. Scrubland plays an important role in providing food but can also provide protection if the shrub layer is high enough to cover a standing ibex. The normalized difference vegetation index, recently linked to the body condition of 


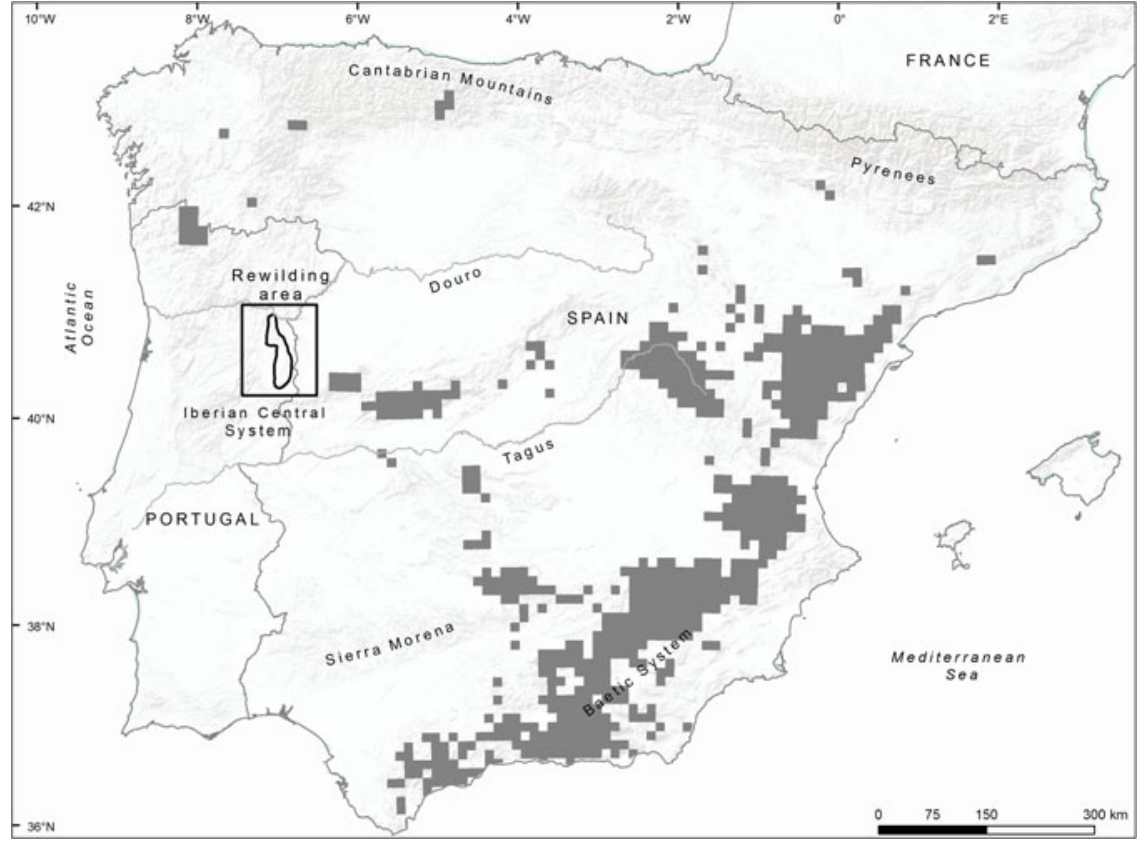

FIG. 1 Location of the study area in the Iberian Peninsula. Grey shaded cells represent UTM $10 \times 10 \mathrm{~km}$ grid cells where the Iberian ibex Capra pyrenaica was recorded. The rewilding area is an area identified as having high favourableness for the reintroduction of the Iberian ibex.

TABLE 1 Variables used to assess the environmental favourableness of habitat patches in Western Iberia (Fig. 1) for the Iberian ibex Capra pyrenaica, with their mean values per UTM $10 \times 10 \mathrm{~km}$ grid cell in the Iberian Peninsula and throughout the species' range.

\begin{tabular}{|c|c|c|}
\hline \multirow[b]{2}{*}{ Variable } & \multicolumn{2}{|l|}{ Mean (Range) } \\
\hline & Iberian Peninsula & Iberian ibex range \\
\hline Slope $\left(^{\circ}\right)$ & $9.15(0-39.47)$ & $12.77(3.05-25.83)$ \\
\hline Forest stands (\%) & $18.61(0-95.10)$ & $23.50(0-90.60)$ \\
\hline Scrubland (\%) & $14.82(0-100)$ & $23.63(0-91.10)$ \\
\hline Agricultural fields (\%) & $39.67(0-100)$ & $26.61(0-99.10)$ \\
\hline Human population density (individuals $\mathrm{km}^{-2}$ ) & $108(0-26,453)$ & $45(0-6,136)$ \\
\hline Road density $\left(\mathrm{km} \mathrm{km}^{-2}\right)$ & $0.24(0-6.63)$ & $0.20(0-0.55)$ \\
\hline Normalized difference vegetation index & $0.43(-0.3-0.85)$ & $0.43(0.19-0.76)$ \\
\hline
\end{tabular}

Iberian ibexes (Carvalho et al., 2015), was used as a proxy for vegetation productivity (Pettorelli, 2013). The slope was used as an index of topographic heterogeneity. We also included two variables that accounted for human disturbance: population density and road density. All variables were handled and processed in ArcGIS v. 10.o (ESRI, Redlands, USA).

Our approach consisted of two main steps. Firstly, we identified favourable areas in the Iberian Peninsula, using logistic regression modelling and a forward-backward stepwise procedure with UTM $10 \times 10 \mathrm{~km}$ cells. Secondly, we downscaled the favourableness values to Western Iberia, with UTM $1 \times 1 \mathrm{~km}$ cells. Finally, we evaluated the connectivity between the favourable localities in Western Iberia, using a graph-based method (Fig. 2).

\section{Environmental favourableness}

The extent of the study area affects the outputs of species distribution modelling (Barve et al., 2011; Acevedo et al.,
2012). By modelling the species distribution with the thirddegree polynomial of the spatial coordinates as predictors (trend surface analysis; Acevedo et al., 2012) we delimited the territory adequate to model the distribution of the Iberian ibex. This procedure selected 5,702 UTM $10 \times 10$ $\mathrm{km}$ cells, of which the Iberian ibex was reported in 645 cells. The ecogeographical drivers of distribution of the Iberian ibex were determined on the basis of the locations in which the species currently occurs. Prior to modelling, the database was divided into training $(80 \%, 4,561$ grid cells) and validation $(20 \%, 1,141$ grid cells) datasets. To avoid problems with multicollinearity we quantified the variance inflation factor in the training dataset and excluded predictors with a variance inflation factor $>10$ from the analyses (Montgomery \& Peck, 1992). Variance inflation factors were calculated for each predictor as the inverse of the coefficient of non-determination of the regression of each predictor against all others, using $H H$ (Heiberger, 2012) in $R$ v.3.2.3 (R Development Core Team, 2016). The 


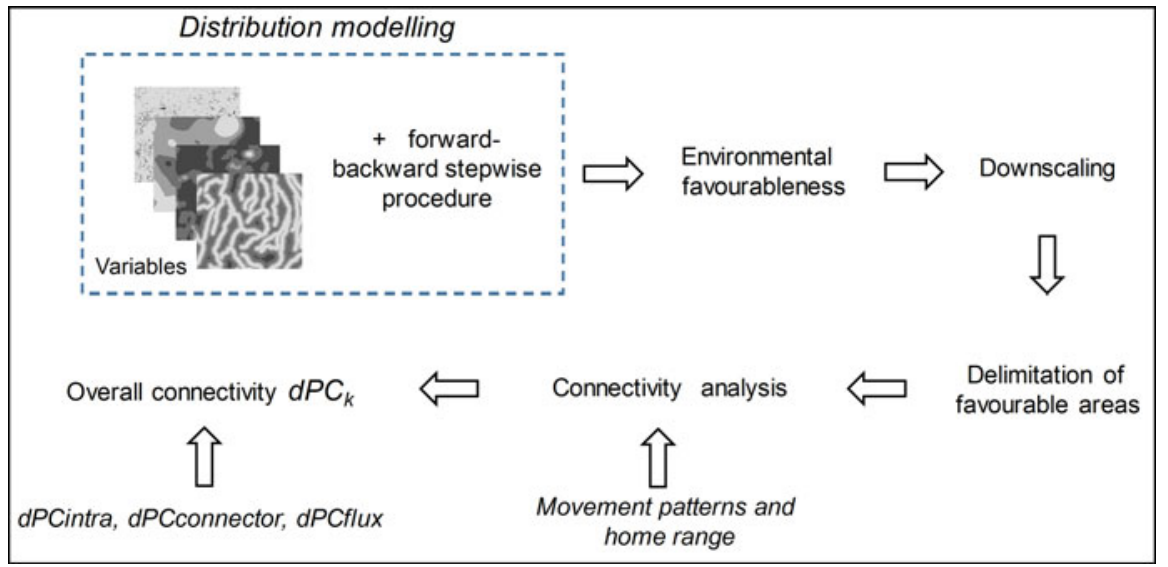

FIG. 2 The approach used to model the environmental favourableness of Western Iberia for the Iberian ibex and the connectivity between habitat patches. predictors selected after controlling the variance inflation factor were considered in a multiple logistic regression (Hosmer \& Lemeshow, 1989) in which the presence or absence of $C$. pyrenaica was used as the response variable. The final model was obtained using a forwards-backwards stepwise procedure based on the Akaike information criterion. Predictions from the logistic regression were included in the favourableness function to make the predicted values independent of the species' prevalence in the study area (Real et al., 2006). The favourableness values are interpretable in absolute terms and can therefore be used as a threshold to identify favourable and unfavourable areas for the species (Acevedo \& Real, 2012). Predictive performance of the final model was assessed on the validation dataset and includes the discrimination capability (area under the receiver operating characteristic curve, AUC). The resolution at which distribution data are available does not always match with the interests of conservation and management. Changes in the spatial resolution of model predictions (i.e. downscaling: the projection of models built at one resolution to a finer spatial resolution) hold potential benefit for ecology and conservation (e.g. Barbosa et al., 2010). Thus, the final model was downscaled to UTM $1 \times 1 \mathrm{~km}$ cells in Western Iberia, to carry out the connectivity analyses.

\section{Patch connectivity}

Graph theory has been suggested as an effective and flexible procedure to assess landscape connectivity (Pascual-Hortal \& Saura, 2006; Saura \& Torné, 2009; Saura \& Rubio, 2010). Within this framework the landscape is described as a set of habitat patches (nodes) and their connecting elements (links; for more details see Saura \& Rubio, 2010). A link represents the functional connectivity (i.e. the likelihood of dispersal between two habitat patches) and can correspond to an ecological/physical corridor or the dispersal ability of the species. All habitat patches with a certain area are considered to be landscape elements. The habitat patch is described by an attribute value, such as habitat area or habitat suitability (Pascual-Hortal \& Saura, 2006). In this case the attribute value of the habitat patch was the area quality, which corresponds to the habitat area divided by the favourableness value derived from modelling. To assess functional connectivity specifically in relation to the Iberian ibex it is essential to include the species' dispersal ability. According to previous studies the mean dispersal distance of the Iberian ibex is $1.25 \mathrm{~km}$ ( $0.7 \mathrm{~km}$, Alados \& Escós, 1985; $1.8 \mathrm{~km}$, Escós, 1988). The landscape connectivity was evaluated via the probability of connectivity index (PC; Saura \& Pascual-Hortal, 2007; Saura \& Torné, 2009). This is expressed as the probability that two points arbitrarily located within the landscape are in habitat areas that are accessible from each other (i.e. interconnected; Saura \& Pascual-Hortal, 2007). Node importance $(d)$ expresses the importance of each habitat patch for the overall connectivity (Saura \& Torné, 2009). The $d \mathrm{PC}$ value can then be divided into three components considering the various ways in which a certain landscape element $i$ (patch or link) can contribute to overall habitat connectivity in the landscape:

$$
d \mathrm{PC}_{\mathrm{i}}=d \mathrm{PC}_{\text {intra }}+d \mathrm{PCflux}_{\mathrm{i}}+\text { dPCconnector }_{i}
$$

where $d \mathrm{PCintra} \mathrm{i}_{\mathrm{i}}$ is the contribution of patch $i$ in terms of intrapatch connectivity, $d \mathrm{PCflu} x_{\mathrm{i}}$ corresponds to the dispersal flux through the connections of patch $i$ to or from all of the other patches in the landscape when $i$ is either the initial or ending patch of that connection ( $d$ PCflux depends both on the attribute value of patch $i$-all things being equal, a patch with a higher attribute value produces more flux-and on its position within the landscape), and $d$ PCconnector $_{i}$ is the contribution of patch or link $i$ to the connectivity between other habitat patches, as a connecting element or stepping stone between them. dPCconnector is dependent only on the topological location of a patch or link within the landscape.

The connectivity analyses were done only after downscaling the model to the Western Iberia region. To evaluate the importance of habitat patches for landscape connectivity, and thus to identify optimal sites for future Iberian ibex 


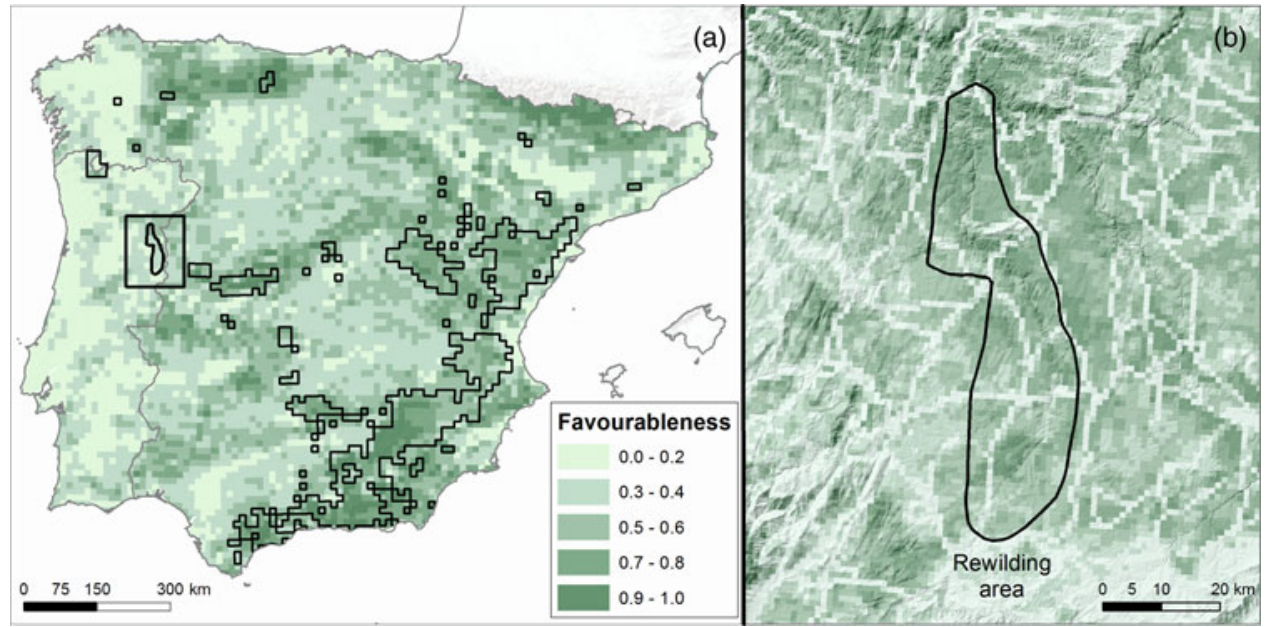

Fig. 3 (a) Environmental favourableness of UTM $10 \times 10$ $\mathrm{km}$ grid cells for the Iberian ibex in the Iberian Peninsula and (b) in Western Iberia after downscaling to UTM $1 \times 1 \mathrm{~km}$ cells. The rewilding area is an area identified as having high favourableness for the reintroduction of the Iberian ibex.

TABLE 2 Variables (Table 1) retained in the environmental favourableness model, with their associated coefficients ( $\beta$ ), standard error (SE), Wald test values and statistical significance $(\mathrm{P})$.

\begin{tabular}{|c|c|c|c|c|}
\hline Variables & $\beta$ & SE & Wald value & $\mathrm{P}$ \\
\hline (Intercept) & -1.09 & 0.26 & -4.25 & $<0.01$ \\
\hline Slope & 0.16 & 0.01 & 12.58 & $<0.01$ \\
\hline Forest stands & 0.03 & 0.00 & 8.41 & $<0.01$ \\
\hline Scrubland & 0.02 & 0.00 & 7.64 & $<0.01$ \\
\hline Agricultural fields & -0.004 & 0.002 & -2.11 & $<0.05$ \\
\hline Human population density & -0.001 & 0.0004 & -1.84 & 0.06 \\
\hline Road density & -2.10 & 0.48 & -4.36 & $<0.01$ \\
\hline Normalized difference vegetation index & -7.18 & 0.61 & -11.82 & $<0.01$ \\
\hline
\end{tabular}

reintroductions, we used Conefor 2.6 and its geographical information system extensions (Saura \& Torné, 2009).

\section{Results}

\section{Environmental favourableness}

Our model facilitated the identification of a set of favourable areas for Iberian ibex in the Iberian Peninsula (Fig. 3). Circa $32 \%$ of the Peninsula has environmental favourableness $>0.5$ and the species is already present in $27 \%$ of this area. In Western Iberia the environmental favourableness for the species varied throughout the region. The north-centre of the study area was associated with patches of dense shrub layer, rough and sloping ridge tops and valleys, low human population and low road density (Table 2). The final model showed good predictive discrimination at the original $10 \times 10 \mathrm{~km}$ resolution $(\mathrm{AUC}=0.79)$.

\section{Patch connectivity}

The relative importance of each landscape element for overall habitat connectivity for the Iberian ibex (as quantified by $d \mathrm{PC}$ and its three components: dPCintra, dPCflux and $d$ PCconnector) was heterogeneously distributed in the landscape; however, the most important landscape elements were located in the north and central areas of the study area (Table 3; Fig. 4). Our results indicate that landscape element 1 and landscape element 2 (Fig. 4) were the most important landscape elements in maintaining the functionality of habitat connectivity for the Iberian ibex. Landscape element 1 had the highest contribution to the overall connectivity $(d \mathrm{PC}=19 \%)$ and the highest values of the $d$ PCflux component (12\%), followed by landscape element 2 ( $d \mathrm{PC}=18 \%)$, with the highest values of the $d \mathrm{PC}$ connector component (13\%; Table 3). Landscape element 1 was well connected to the other habitat patches within the dispersal distance of the Iberian ibex (high $d$ PCflux), whereas landscape element 2 was strategically located to sustain the connectivity between other habitat patches (high $d$ PCconnector). Both landscape elements 3 and 4 had the second highest values of $d \mathrm{PC} f l u x$ and $d \mathrm{PC}$ connector (landscape element 3: $d \mathrm{PCflux}=9 \%, d \mathrm{PC}$ connector $=8 \%$; landscape element 4: $d \mathrm{PC}$ flux $=8 \%, d \mathrm{PC}$ connector $=6 \%$ ). Landscape elements 5 and 6 had the highest values of $d$ PCintra ( $2 \%$ for each; Table 3). Landscape element 2 had the highest $d \mathrm{PC}$ connector, followed by landscape element 3 (Table 3). 
TABLE 3 Contribution of each landscape element (i.e. habitat patch) to the maintenance of the overall landscape connectivity as measured by $d \mathrm{PC}$ (overall habitat connectivity), $d$ PCintra (contribution of each patch to intrapatch connectivity), $d \mathrm{PC} f l u x$ (depends on both the attribute value of a patch and its position within the landscape) and $d$ PCconnector (contribution of each patch to the connectivity between other patches, as a connecting element or stepping stone between them) (Fig. 4).

\begin{tabular}{llllrr}
\hline & Area $\left(\mathrm{km}^{2}\right)$ & $d \mathrm{PC}$ & dPCintra & dPCflux & dPCconnector \\
\hline Landscape element 1 & 55.09 & 18.77 & 1.45 & 11.48 & 5.84 \\
Landscape element 2 & 25.04 & 18.12 & 0.24 & 5.36 & 12.52 \\
Landscape element 3 & 39.06 & 17.90 & 0.80 & 8.97 & 8.15 \\
Landscape element 4 & 39.07 & 15.13 & 0.65 & 10.88 & 6.01 \\
Landscape element 5 & 65.13 & 14.27 & 2.22 & 8.26 & 1.18 \\
Landscape element 6 & 63.10 & 11.87 & 2.29 & 1.33 \\
\hline
\end{tabular}

\section{Discussion}

We identified favourable areas that could serve as potential nuclei of reintroduction for the Iberian ibex in the Iberian Peninsula, which in turn could lead to establishment of the species and expansion of its distribution. The Western Iberia region is strategically located to enhance the natural expansion of existing populations, including the nearby Spanish population in the Sierra de las Batuecas. Furthermore, the region is characterized by well-connected habitat patches and relatively low human pressure, offering favourable conditions for reintroduction and establishment of the Iberian ibex. The species would have access to continuous habitat to fulfil its ecological requirements, increasing the likelihood of its long-term survival. Previous studies have highlighted the importance of protecting and enhancing existing favourable areas to facilitate the dispersal and survival of the species (Schadt et al., 2002; Bleyhl et al., 2015). The favourable areas that were identified in the north and centre of Western Iberia could potentially serve as reintroduction nuclei (Fig. 4), and their strategic location would facilitate the movement of populations among the nuclei. The areas with highest favourableness include dense vegetation, well-developed tree cover interspersed with areas with a continuum of dense and sparse shrub layer, and a rich herbaceous layer, which provide refuge and feeding places for species establishment and reproduction. Additionally, forest stands and tall shrub may serve as ecological corridors for range expansion. The species' preference for low-disturbance regions has already been shown (Acevedo \& Cassinello, 2009). In an area with low disturbance, such as the study area, the main threats to the Iberian ibex are the increasing presence of domestic livestock, which can act as reservoirs of wildlife diseases, and interspecific competition for resources (Acevedo et al., 2007b).

After assessing the existence of favourable habitats we evaluated whether they were sufficiently well connected to facilitate movement between populations and ensure that suitable patches could be colonized. By ranking the contribution of each landscape element to the maintenance of the overall landscape connectivity we identified high-priority habitat patches for future conservation and management actions. Specifically, our results show that the central area of Western Iberia plays a fundamental role in the dispersal of the Iberian ibex. The landscape elements are strategically located (e.g. in a central position) and are large and well connected to the other habitat patches within the dispersal distance of the species (high intra-patch connectivity). Moreover, they enhance the connectivity between the north, south and eastern parts of the study area, which will promote the natural expansion of the existing populations on the Spanish side. Specifically, both landscape elements 3 and 4 had high contributions to overall connectivity because they are well connected to other habitat patches within the dispersal distance of the Iberian ibex (high $d \mathrm{PC} f l u x$ ) and are large enough and centrally located, supporting connectivity between other habitat patches (high $d \mathrm{PC}$ connector). Landscape elements 5 and 6 have the largest total area $\left(\mathrm{A}_{\mathrm{L}}\right)$ and therefore high $d \mathrm{PCintra}$. Landscape elements 2 and 3 , in the central part of the study area, have the highest $d$ PCconnector (i.e. they may function as stepping stones between other isolated patches), highlighting the high probability of colonization of these habitat patches. Stepping stones are known to be fundamental for the spread of species (Carranza et al., 2012; Saura et al., 2014). Fragmentation of the vital core area would probably impede establishment of the Iberian ibex. Connectivity between habitat patches has been shown to be important in securing genetic flux between populations, increasing the efficiency of reintroduction programmes (Olech \& Perzanowski, 2002). According to the dispersal characteristics of the Iberian ibex (Escós, 1988; Alados \& Escós, 1985), natural dispersal to the south and east of the study area is expected, as there are potentially effective connections between the reintroduction sites and the southern habitat patches. By quantifying the importance of each habitat area it is possible to focus conservation and management actions directly in areas that have greater importance for overall connectivity.

We suggest that the approach used here for the Iberian ibex in Western Iberia could be extended to other species and conservation purposes, and is particularly important in reintroduction projects where species data are not 
(a) Overall connectivity ( $d \mathrm{PC})$

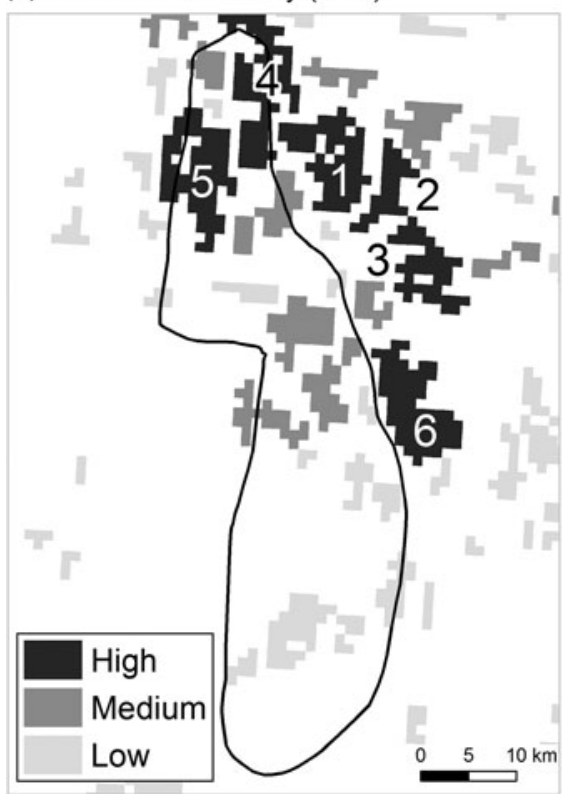

(c) dPCconnector

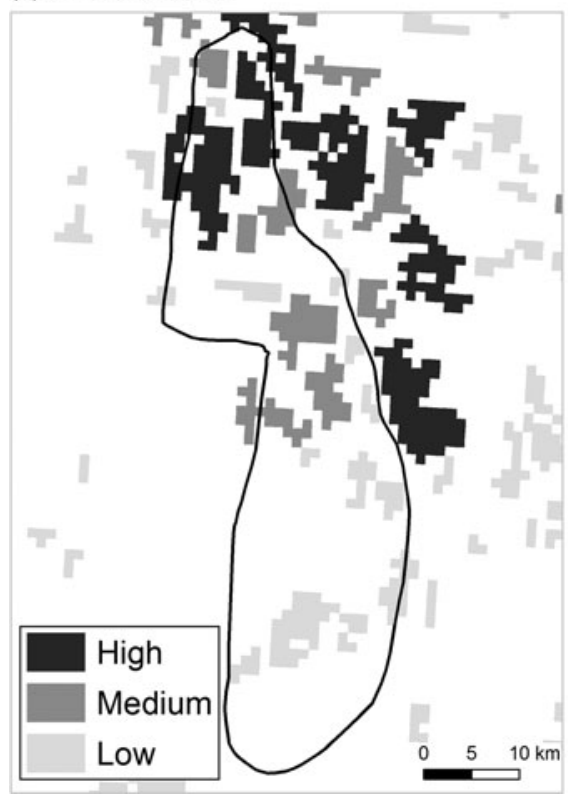

(b) dPCintra

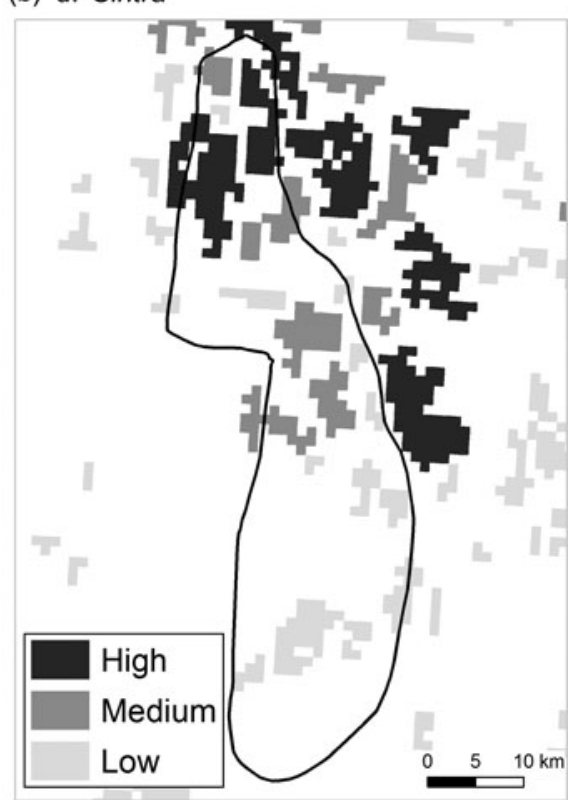

(d) dPCflux

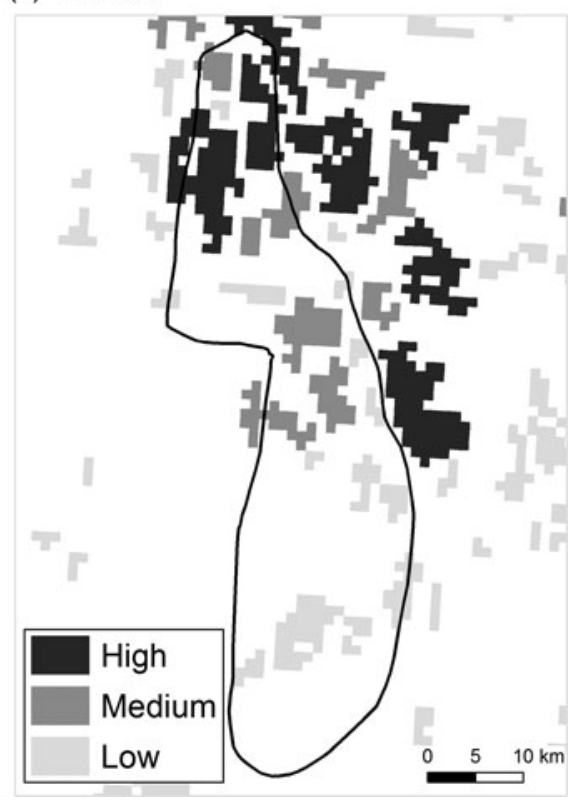

FIG. 4 (a) The importance of each of six landscape elements (numbered) in maintaining overall connectivity $(d \mathrm{PC})$ for the Iberian ibex in the study area in Western Iberia, and the importance of the components (b) dPCintra, (c) dPCconnector, and (d) $d$ PCflux. available. However, the success of reintroduction programmes depends not only on evaluating favourable and connected areas but also on the ability to manage them appropriately (Jepson, 2015). A main goal of the EU Biodiversity Action Plan is to restore $15 \%$ of the EU's degraded or abandoned land, and the creation of a functional ecosystem through rewilding would contribute to achieving this goal. Our proposed methodology for identifying highpriority habitats in target areas is a valuable tool for conservation planning, helping to determine high-priority habitats within target areas. This is particularly significant as rewilding projects are assuming a more widespread role in restoring degraded landscapes (Jepson, 2015).

\section{Acknowledgements}

We are grateful for the support of the Associação de Transumância e Natureza. JC was supported by a $\mathrm{PhD}$ grant (SFRH/BD/98387/2013), ES by a postdoctoral programme (SFRH/BPD/96637/2013) of the Fundação para a Ciência e a Tecnologia, (FCT), Portugal, and PA by the Spanish Ministerio de Economía y Competitividad and Universidad de Castilla-La Mancha through a Ramón y Cajal contract (RYC-2012-11970). We thank the University of Aveiro (Department of Biology) and Fundação para a Ciência e a Tecnologia/Ministério da Ciência, Tecnologia e Ensino Superior (FCT/MEC) for the financial support to 
Centro de Estudos do Ambiente e do Mar Research Unit (CESAM RU) (UID/AMB/50017) through national funds, co-financed by the Fundo Europeu de Desenvolvimento Regional (FEDER) within the PT2020 Partnership Agreement.

\section{Author contributions}

RTT and JC conceived and designed the research, analysed data and wrote the manuscript. PA analysed data. All authors contributed to the development of ideas.

\section{References}

Acevedo, P. \& Cassinello, J. (2009) Biology, ecology and status of Iberian ibex Capra pyrenaica: a critical review and research prospectus. Mammal Review, 39, 17-32.

Acevedo, P., Cassinello, J., Hortal, J. \& Gortazar, C. (2007a) Invasive exotic aoudad (Ammotragus lervia) as a major threat to native Iberian ibex (Capra pyrenaica): a habitat suitability model approach. Diversity and Distributions, 13, 587-597.

Acevedo, P., Cassinello, J. \& Gortazar, C. (2007b) The Iberian ibex is under an expansion trend but displaced to suboptimal habitats by the presence of extensive goat livestock in central Spain. Biodiversity and Conservation in Europe, 16, 3361-3376.

Acevedo, P., Jiménez-Valverde, A., Lobo, J.M. \& Real, R. (2012) Delimiting the geographical background in species distribution modelling. Journal of Biogeography, 39, 1383-139o.

Acevedo, P. \& Real, R. (2012) Favourability: concept, distinctive characteristics and potential usefulness. Naturwissenschaften, 99, 515-522.

Alados, C.L. \& Escós, J. (1985) La cabra montés de las sierras de Cazorla y Segura. Una introducción al estudio de sus poblaciones y comportamiento. Naturalia Hispanica, 28, 36.

Armstrong, D.P. \& Seddon, P.J. (2008) Directions in reintroduction biology. Trends in Ecology \& Evolution, 23, 20-25.

Barbosa, A.M., Real, R. \& VArgas, J.M. (2010) Use of coarse-resolution models of species' distributions to guide local conservation inferences. Conservation Biology, 24, 1378-1387.

Barve, N., Barve, V., Jiménez-Valverde, A., Lira-Noriega, A., Maher, S.P., Peterson, A.T. et al. (2011) The crucial role of the accessible area in ecological niche modeling and species distribution modeling. Ecological Modelling, 222, 1810-1819.

Bleyhl, B., Sipko, T., Trepet, S., Bragina, E., Leitão, P.J., Radeloff, V.C. \& Kuemmerle, T. (2015) Mapping seasonal European bison habitat in the Caucasus Mountains to identify potential reintroduction sites. Biological Conservation, 191, 83-92.

Byers, J.E., Cuddington, K., Jones, C.G., Talley, T.S., Hastings, A., Lambrinos, J.G. et al. (2006) Using ecosystem engineers to restore ecological systems. Trends in Ecology \& Evolution, 21, 493-500.

Cabral, M.J., Almeida, J., Almeida, P.R., Dellinger, T., Ferrand De Almeida, N., Oliveira, M., et al. (2005) Livro vermelho dos vertebrados de Portugal. Instituto da Conservação da Natureza, Lisbon, Portugal.

Cabrera, A. (1911) The subspecies of the Spanish ibex. Proceedings of the Zoological Society of London, 81, 963-977.

Carranza, M.L., D’Alessandro, E., Saura, S. \& Loy, A. (2012) Connectivity providers for semi-aquatic vertebrates: the case of the endangered otter in Italy. Landscape Ecology, 27, 281-290.
Carvalho, J., Granados, J.E., López-Olvera, J.R., Cano-Manuel, F.J., Pérez, J.M., Fandos, P. et al. (2015) Sarcoptic mange breaks up bottom-up regulation of body condition in a large herbivore population. Parasites \& Vectors, 8, 1-9.

Chauvenet, A.L., Parlato, E.H., Gedir, J.V. \& Armstrong, D.P. (2015) Advances in modelling projections for reintroduced populations. In Advances in Reintroduction Biology of Australian and New Zealand Fauna (eds D.P. Armstrong, M.W. Hayward, D. Moro \& P.J. Seddon). CSIRO Publishing, Clayton, Australia.

Cianfrani, C., Maiorano, L., Loy, A., Kranz, A., Lehmann, A., Maggini, R. \& Guisan, A. (2013) There and back again? Combining habitat suitability modelling and connectivity analyses to assess a potential return of the otter to Switzerland. Animal Conservation, 16, 584-594.

Escós, J. (1988) Estudio sobre la ecología y etología de la cabra montés (Capra pyrenaica hispanica Schimper, 1848) de las Sierras de Cazorla y Segura y Sierra Nevada oriental. PhD thesis. Universidad de Granada, Granada, Spain.

Granados, J.E., Pérez, J.M., Márquez, F.J., Serrano, E., Soriguer, R.C. \& Fandos, P. (2001) La cabra montés (Capra pyrenaica, Schinz 1838). Galemys, 13, 3-37.

Heiberger, R.M. (2012) HH: statistical analysis and data display: Heiberger and Holland. R package version 2.3-27. Http://CRAN. R-project.org/package $=\mathrm{HH}$ [accessed 5 July 2016].

Helmer, W., SaAvedra, D., Sylvén, M. \& Schepers, F. (2015) Rewilding Europe: a new strategy for an old continent. In Rewilding European Landscapes (eds H.M. Pereira \& L. Navarro), pp. 171-19o. Springer International Publishing, New York, USA.

Herrero, J. \& Pérez, J.M. (2008) Capra pyrenaica. The IUCN Red List of Threatened Species 2008: e.T3798A10085397. Http://dx.doi. org/10.2305/IUCN.UK.2008.RLTS.T3798A10085397.en [accessed 12 August 2016].

Höchtl, F., Lehringer, S. \& Konold, W. (2005) "Wilderness": what it means when it becomes a reality - a case study from the southwestern Alps. Landscape and Urban Planning, 70, 85-95.

Hosmer, D.W. \& Lemeshow, S. (1989) Applied Logistic Regression. John Wiley and Sons, New York, USA.

JEPSON, P. (2015) A rewilding agenda for Europe: creating a network of experimental reserves. Ecography, 38, 1-8.

MacDonald, D., Crabtree, J.R., Wiesinger, G., Dax, T., Stamou, N., Fleury, P. et al. (2000) Agricultural abandonment in mountain areas of Europe: environmental consequences and policy response. Journal of Environmental Management, 59, 47-69.

Manning, A.D., Gordon, I.J. \& Ripple, W.J. (2009) Restoring landscapes of fear with wolves in the Scottish Highlands. Biological Conservation, 142, 2314-2321.

McKnight, R. (2014) Rewilding the European landscape: an unconventional approach to land management. City Wild. Paper 8.

Moço, G., Guerreiro, M., Ferreira, A.F., Rebelo, A., Loureiro, A., Petrucci-Fonseca, F. \& Pérez, J.M. (2006) The ibex Capra pyrenaica returns to its former Portuguese range. Oryx, 40, 351-354.

Moço, G., Serrano, E., Guerreiro, M., Ferreira, A.F., Petrucci-Fonseca, F., Maia, M.J. et al. (2013) Seasonal dietary shifts and selection of Iberian wild goat Capra pyrenaica Schinz, 1838 in Peneda-Gerês National Park (Portugal). Galemys, 25, 13-27.

Montgomery, D.C. \& Peck, E.A. (1992) Introduction to Linear Regression Analysis. Wiley, New York, USA.

Olech, W. \& Perzanowski, K. (2002) A genetic background for reintroduction program of the European bison (Bison bonasus) in the Carpathians. Biological Conservation, 108, 221-228.

Pascual-Hortal, L. \& Saura, S. (2006) Comparison and development of new graph-based landscape connectivity indices: towards the prioritization of habitat patches and corridors for conservation. Landscape Ecology, 21, 959-967. 
Perea, R., Perea-García-Calvo, R., Díaz-Ambrona, C.G. \& San Miguel, A. (2015) The reintroduction of a flagship ungulate Capra pyrenaica: assessing sustainability by surveying woody vegetation. Biological Conservation, 181, 9-17.

Pérez, J.M., Granados, J.E., Soriguer, R.C., Fandos, P., Márquez, F.J. \& Crampe, J.P. (2002) Distribution, status and conservation problems of the Spanish ibex, Capra pyrenaica (Mammalia: Artiodactyla). Mammal Review, 32, 26-39.

Pettorelli, N. (2013) The Normalized Difference Vegetation Index. Oxford University Press, Oxford, UK.

R Development Core Team (2016) R: A Language and Environment for Statistical Computing. R Foundation for Statistical Computing, Vienna, Austria.

Real, R., Barbosa, A.M. \& Vargas, J.M. (2006) Obtaining environmental favourability functions from logistic regression. Environmental and Ecological Statistics, 13, 237-245.

Sandom, C., Bull, J., Canney, S. \& Macdonald, D.W. (2012) Exploring the value of wolves (Canis lupus) in landscape-scale fenced reserves for ecological restoration in the Scottish Highlands. In Fencing for Conservation (eds M.J. Somers \& M.W. Hayward), pp. 245-276. Springer, New York, USA.

Saura, S., Bodin, Ö. \& Fortin, M.-J. (2014) Stepping stones are crucial for species' long-distance dispersal and range expansion through habitat networks. Journal of Applied Ecology, $51,171-182$.

Saura, S. \& Pascual-Hortal, L. (2007) A new habitat availability index to integrate connectivity in landscape conservation planning: comparison with existing indices and application to a case study. Landscape and Urban Planning, 83, 91-103.

Saura, S. \& Rubio, L. (2010) A common currency for the different ways in which patches and links can contribute to habitat availability and connectivity in the landscape. Ecography, 33, 523-537.

SAURA, S. \& Torné, J. (2009) Conefor Sensinode 2.2: a software package for quantifying the importance of habitat patches for landscape connectivity. Environmental Modelling \& Software, 24, 135-139.
Schadt, S., Revilla, E., Wiegand, T., Knauer, F., Kaczensky, P., Breitenmoser, U. et al. (2002) Assessing the suitability of central European landscapes for the reintroduction of Eurasian lynx. Journal of Applied Ecology, 39, 189-203.

Tenorio, M.C., Juaristi, C.M. \& Ollero, H.S. (2005) Los Bosques Ibéricos. Una interpretación geobotánica. Editorial Planeta, Barcelona, Spain.

Theil, S., Elkin, M., Underhill, W., Pape, E. \& Rogacin, W. (2005) Into the woods: economics and declining birthrates are pushing large swaths of Europe back to their primeval state, with wolves taking the place of people. Newsweek, 146, 30.

VAn de Vlasakker, J. (2014) Rewilding Europe Bison Rewilding Plan 2014-2024. Rewilding Europe, Nijmegen, The Netherlands.

Vos, W. \& Meekes, H. (1999) Trends in European cultural landscape development: perspectives for a sustainable future. Landscape and Urban Planning, 46, 3-14.

\section{Biographical sketches}

Rita Tinoco Torres's research is focused primarily on the ecology and management of ungulates, and their role as reservoirs of infectious diseases at the human-livestock-wildlife interface. Jo ̃̃ O CARVALHO is interested in wildlife management, ecological and evolutionary consequences of selective harvesting in ungulates, multiparasitism, cartography and geographical information systems. EMMANUEL SERRANO is interested in the impact of infectious diseases and environmental variation on life history traits of individuals and populations, with a particular focus on ungulates. WOUTER HELMER has more than 30 years of experience in large-scale rewilding programmes. As member of the Rewilding Europe team his main focus is on the restoration of natural processes and key wildlife species. PELAYO ACEVEDo is focused on the multidisciplinary framework in which wildlife species and their parasites are studied at local and large spatial scales. CARLOS FONSECA has broad interests in wildlife ecology, conservation and management, with a particular interest in ungulates. 